\title{
The Political Rights of Women in the Light of Islamic
} Jurisprudence

\section{ABSTRACT:}

*Dr. Khadija Aziz

Dr. Abid Iqbal

Accordingly, the meaningful participation of women in national, local, and community leadership roles has become an important focus on global development policy. Allah (SWT) has given a due and most suitable status to the women. Women in leadership positions have been mentioned in multiple occasions in Quran. Islam gave them the right to vote and remain politically active in legislative, executive, and judiciary. "Then whoever disputed with you about him after all this knowledge that has come to you, say: 'Come, let us call our sons and your sons, our women and your women, ourselves and yourselves, then we pray and invoke sincerely the curse of Allah upon those who lie", .

Quran and hadith were used as primary sources for the collection of authentic information, whereas published data on subject was used as secondary sources.

Key words: political rights, pledge of Aqabah, dowry, judge.

\section{INTRODUCTION:}

Beside the other rights, the great religion Islam has imparted women with sound political rights. However, a large number of women are ignorant of the political rights bestowed to them by the holy Quran and Sunnah of prophet SAW). Hence they are benefiting their selves from such privileges.

Islam, the complete code of life for humanity, makes sure that guiding principles be available to its followers from every aspect of human life. It has decided all those codes and protocols that lead in the direction of progress and forthcoming social issues. Being physical superior, the responsibility of protecting women has been assigned to men by almighty Allah. This natural difference has been misinterpreted by non-Muslims and they have put a blame of conservation on Islam which is not realistic.

The political rights of women have been derived from the holy Quran and Sunnah, while their further clarification is evident from the deeds of prominent personalities of the Islamic history. Women can cast their vote, can be appointed as judge and can even play vital role in influencing legal decisions inside courts.

A government contains three basic tiers i.e. legislative, executive and judiciary. Women can play their effective role in all three state affairs, provided they observe the limits imposed by Islam. The most prominent and obligatory limitation is that, women's involvement in state affairs should not invite lecherous and lustful eyes and

"Department of Islamiyat, Shaheed Benazir Bhutto Women University, Peshawar.

Email:khadijaaziz@sbbwu.edu.pk

** Department of Islamic Studies, Govt; Degree College Lahor Swabi. 
free intermixing with men. They have to wear their complete attire, as directed by Quran.

1: Don't display yourself like that of the times of the ignorance ${ }^{2}$.

2: "O prophet (SAW) tell your wives and your daughter's the women of the believers to draw their cloacks (veils) all over their bodies, that will be better, that they should be known as free respectable women) so as not to be annoyed",3.

\section{Qura'anic Verses that Support Women's Involment in Political Affairs:}

Women in leadership positions have been mentioned in multiple occasions in Quran. Islam gave them the right to vote and remain politically active. Involving women in sate affairs is evident and supported by "Ayat-e Mabahala", in which if on one side men have to participate from either group, women also have to be called on the spot of this ordeal. This verse states ${ }^{4}$.

"Then who ever disputed with you about him after all this knowledge that has come to you, say: 'Come, let us call our sons and your sons, our women and your women, ourselves and yourselves, Then we pray and invoke sincerely the curse of Allah upon those who lie" $"$.

Although this verse was properly revealed, regarding the truth about Hazrat Esa (A.S) but in addition also proves that women too have rights to participate in political and public affairs and can be trusted upon just like men participants.

According to the Holy Quran; "The believing men and believing women are allies of one another. They enjoin what is right and forbid what is wrong and establish prayer and give zakah and obey Allah and his messenger. Allah will have mercy upon them. Indeed, Allah is exalted in Might and wise" 6

Muhammad Rashid Raza, a distinguished religion scholar of the current time, writes under the elaboration of this verse, that the holy Quran had put the responsibility of participating in social affairs, mutually and equally over men and women ${ }^{7}$.

In the same context, another verse states that, "O Prophet, when the believing women come to you pledging to you that they will not associate anything with Allah, nor will they steal, nor will they commit unlawful sexual intercourse, nor will they kill their children, nor will they bring forth a slander they have invented between their arms and legs, nor will they disobey you in what is right then accept their pledge and ask forgiveness for them of Allah. Indeed, Allah is forgiving and merciful""

This verse specifically states that women can pledge allegiance to state head. It is narrated that pledging the women, the Prophet (SAW) did not shake hands with women, rather he (SAW) used to put them to the question and if they agreed, he said "you may go". Thus in a pledge the ruler used to get public assurance about subordination to him".

In the modern time, vote is a modified form of pledge, where the destination of people is determined by the way of casting a vote in favor of favorite candidate contesting the election. It will not be justified to forbid women from deciding their future. It is a trust as well as a right and to be used for the selection of right person. Allah may, He be glorified said; "Indeed, Allah commands you to rendered trust to whom they are due"10. 


\section{Political Role of Women in the Light of Sunnah:}

The holy Prophet (SAW) performed the religious duties perfectly in all parts of human life, including the direction and practice commanding women's role by settling the best example for all the Muslims to follow him. For instance, narration of Mueed bin kaab, said when they assembled in shaab near aqabah where 72 men and several women including Nasibah bint Kaab ummah ammarah and Asma bint Umer bin addi", 11 . The pledge of aqabah has a political as well as a spiritual implication i.e. the men and women who pledged were not only declaring their faith in Islam, but promising the political support and if deemed essential military protection too, to the prophet (SAW). Hence there is a message that women can enjoy due share in legislative, executive and judicial affairs.

\section{Importance of womens opinion in national affairs:}

The primary function of a legislature is law making, in addition to the supervision of other state affairs. In Islamic states, provision of laws, is the supreme right of Allah Almighty. According to Imam Zaidi (RA), Ayesha (RA) was a great jurist of her time. She was not only an expert of Islamic law but also having expertise in medicine and poetry, the later reported by Ibn Hassan ${ }^{12}$.

The importance of women's opinion in the national and marital affairs can be judged from the action of Hazrat Omar (RA), who even changed his decision about dowry (Haq Mehar or marriage settlement) after a woman presented solid evidence before him. According to the narration ${ }^{13}$. one day Hazrat Omar (RA) mounted the pulpit and sermoned the people;

"O, people, you have increased the dowry to the limit beyond the one fixed during the age of prophet Muhammad (SAW) and the Sahaba (R.A). If anyone marries and fixes a dowry for more than 400 dirham for his wife, I will deposit the excess amount in Bait-al-Mal (public treasury). And if high dowry was a matter of honor and Taqwa from Allah side, then the prophet (SAW) and Sahaba (R.A) would have surpassed you people" ${ }^{, 14}$.

A woman from the audience told "Umar! Are what you say more acceptable or Allah's ordinance? Doesn't Allah Almighty say? "And if you wish to have (one) wife in place of another and you have given one of them a heap of gold, then take not from it anything. Are you taking it illegally and with $\sin " 15$.

Then Omar (R.A) again mounted and said, I now permit you to give as much as you like beyond the specified limit, there is no harm in it.

Womens Participation in the Administrative responsibilities of the State in the light of Islamic Teachings:

Islam doesn't restrict women to work outside their houses. The only condition is that her job should not negatively affect her dignity and high position. The life of the prophet (SAW) reveals that religion permit women to assist men in the provision of food and aid to those wounded on the battle field. Enjoining good and forbidding evil is one of the basic responsibilities of the state. According to the Holy Quran "(They are) those who if we establish them in the land, establish regular prayer and give 
regular charity, enjoin the right and forbid wrong; with Allah rests the end (and decisions) of (all) affairs"16.

\section{Women's Appointement as Judge:}

There is a diversity of opinion regarding women's appointment as a judge, amongst the Muslim jurists. According Maliki, Shafee and Hanbali jurists say that woman cannot be made judge ${ }^{17}$. Such opinions stem from various verses of the Holy Quran, Hadith and the narrated sources such as "Men are the over upright (managers) (of the affairs) of women for what Allah has graced some of them over (others) and because they spend their property (for the support of women) ${ }^{18}$. "And the women also have rights, similar to the obligation on them, according to custom and in a way, the status of men is greater as compared to them, and Allah is dominant, wise",19.

These jurists derive from these holy verses that men have an upper hand over women and giving them legal responsibilities is against this preference. Family protection and care taking is the sole responsibility of men, as in every system the establishment of a dominant head is obligatory. As per the second verse, its initial portion in itself maintains that women have equal rights. "Never will succeed such a nation that makes women their ruler" 20 .

As against this prohibition of women from carrying out judicial punishment another school of thought holds that there is nothing wrong with a female if she is competent and serve at highest levels such as heads, executives, managers and advisors, and in such cases the society will be bound to obey such decision ${ }^{21}$.

The third opinion about women as judge is that of Hanafi School. According to them, there is strict rule for judge to be a male person beside, the restrictive panel ordinance and retaliation law ${ }^{22}$.

\section{Women's role in decision making:}

It is known from the guidance of the Holy Quran and teachings of Prophet (SAW) that women can be consulted in some general and private matters. For instance, Allah (SWT) narrates the leadership and decision making and consulting characteristics of Queen Balqees, who decided to consult her cabinet members, when challenged by Hazrat Suleiman(A.S). Indeed, I found (there) a women ruling them, and she has been given of all things and she has a great throne"23.

She said, "Indeed kings when they enter a city they ruin it and render the honored of its people humbled. And thus do they do" 24 .

Thus, Quran has narrated the political farsightedness of women which reveals that women do have the capacity to be appointed on administrative posts, provided they have the illegibility. It, here, does not depend on whether the administrator is man or woman $^{25}$.

The Holy Prophet (SAW) also sought the consultation of Um-Salamah (R.A) on the day of Al-Hudaybiyyah. He asked according to her view point and achieved the goal. Hazrat Omar (R.A) once asked his daughter Hafsa (R.A) about the maximum duration for which a woman can tolerate the absence of her husband from her? She replied that six or four months. Hazrat Omar (R.A) then said. "I will not let soldier stay abroad 
more than the said period" ${ }^{26}$. It is concluded that women can influence judicial decisions as well and could be consulted.

\section{Results:}

Women in leadership positions have been mentioned in multiple occasions in Quran. Islam gave them the right to vote and remain politically active i.e. "The believing men and believing women are allies of each another. They enjoin what is right and forbid what is wrong and establish prayer and give zakat and obey Allah and his messenger. Allah will have mercy upon them. Indeed, Allah is exalted in Might and wise".

\section{Conclusions:}

The importance of women's opinion in the national and marital affairs can be judged from the action of Hazrat Omar (RA). It is concluded that women can influence judicial decisions and could be consulted.

\section{References:}

${ }^{1}$ Al-Imran,03:61

${ }^{2}$ Al-ahzab,33:33

${ }^{3} \mathrm{Al}-\mathrm{ahzab}, 33: 59$

${ }^{4}$ Ibne Kasser, tafseer ul Quran Alazim, 1/368

${ }^{5} \mathrm{Al}-\mathrm{ahzab}, 33: 33$

${ }^{6}$ Al-toab, 09:71

${ }^{7}$ Muhammad Rasheed raza, Nid Ul Jins Ul Latif, Almanar publisher, Egypt;7

${ }^{8}$ Al-mumtahina, 60:12

9 Jalauddin Muhammad Bin Ahmad, Tafseer Jalalain, Maktaba Albushra, Karachi, Pakistan, vol 3, p: 509

${ }^{10}$ Al-nisa, 04:58

${ }^{11}$ Ibn e Abdul bar, Al-Isteab, vol 1, p: 3

${ }^{12}$ Ibn e hijr, Al-Ahabha, vol 4, p: 27

${ }^{13}$ Ibn e Abdul bar, Al-Isteab, vol 1, p: 3

${ }^{14}$ Al-kanz, vol 16, p: 536-537, (45796)

15 Al-nisa, 04:20

${ }^{16}$ Al-hajj,22:41

${ }^{17}$ Imam Baghavi, Sharah-Al-Sunnah, mmmmm, vol 10, p:77

${ }^{18}$ Al-nisa,04:34

19 Al-baqara,02:228

${ }^{20}$ Al Bukhari, Sahi Al Bukhari, Kitab ul Maghazi, Kitab un Nabi (SWAT), Abi Kasr o Qasran, Hadis: 4425, 7099

${ }^{21}$ Ibn-E-Hizam, Al-Mohali, Vol 8, p: 528, Al-Mawardi, Adab-Ul-Qazi, Vol 1, p: 226

${ }^{22}$ Alkasani, Bada Yagh Alsanaya, Vol 7, p:4

${ }^{23}$ Al-namal,27:23

${ }^{24}$ Al-namal,27:34

${ }^{25}$ Abdul Hameed al matwali. Mubadi nizam ul hokum fel islam. P: 426

${ }^{26}$ Muhammad ghaza darweza. Al marata fel quran wa sunnah. P: 53-54

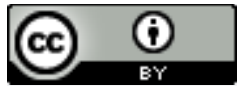

This work is licensed under a Creative Commons Attribution 4.0 International License. 